\title{
The acute phase response protein SERP INA3 is increased in tear fluid from the unaffected eyes of patients with unilateral acute anterior uveitis
}

Jon Roger Eidet ${ }^{1 *}$ (D, Maja Akopian ${ }^{1}$, Ole K. Olstad $^{2}$, Øystein Kalsnes Jørstad ${ }^{1}$, Morten C. Moe $^{1}$, Goran Petrovski ${ }^{1}$ and Milaim Pepaj ${ }^{3}$

\begin{abstract}
Background: To identify candidate tear fluid biomarkers in patients with unilateral acute anterior uveitis (AAU) that can aid in the differentiation between these patients and patients with bacterial keratitis or healthy controls.

Methods: Thirteen patients ( $40.1 \pm 16.2$ years of age) with unilateral AAU, seven patients with unilateral bacterial keratitis ( $40.2 \pm 15.3$ years of age), and 14 healthy subjects ( $41.1 \pm 11.6$ years of age) were included. The tear proteome of affected eyes was compared with that of the unaffected eye or healthy controls. Proteins were identified by liquid chromatography tandem mass spectrometry and enzyme-linked immunosorbent assay.

Results: Relative protein ratios were detected and calculated for 272 unique proteins. Compared with healthy controls and the unaffected eye, the top upregulated proteins in AAU eyes were submaxillary gland androgen regulated protein 3B (SMR3B) and SMR3A. Similarly, the top upregulated proteins in bacterial keratitis were S100 calcium-binding protein $A 9$ and orosomucoid 2. The acute phase response protein Serpin Family A Member 3 (SERPINA3) was increased in the healthy eye of AAU patients $(P=0.019)$ compared with healthy controls. Laser flare measurements in affected eyes of AAU patients showed positive logarithmic correlation with SERPINA3 in tear samples of the unaffected eye $(P=0.022)$. The use of SERPINA3 as a tear biomarker yielded a sensitivity of $85 \%$ and a specificity of $71 \%$ in detecting patients with AAU in the study population.

Conclusions: The acute phase response protein SERPINA3 was increased in tear samples of unaffected eyes of patients with unilateral AAU compared with healthy controls. This study highlights SERPINA3 as a potential biomarker for AAU. Future research should explore the dynamic properties of SERPINA3 in the tear fluid of active and quiescent uveitis eyes.
\end{abstract}

Keywords: Uveitis, Tear fluid, Proteomics, Biomarker

\footnotetext{
* Correspondence: j.r.eidet@gmail.com

${ }^{1}$ Department of Ophthalmology, Center for Eye Research, Oslo University

Hospital and University of Oslo, Oslo, Norway

Full list of author information is available at the end of the article
}

\section{Springer Open}

(c) The Author(s). 2021 Open Access This article is licensed under a Creative Commons Attribution 4.0 International License, which permits use, sharing, adaptation, distribution and reproduction in any medium or format, as long as you give appropriate credit to the original author(s) and the source, provide a link to the Creative Commons licence, and indicate if changes were made. The images or other third party material in this article are included in the article's Creative Commons licence, unless indicated otherwise in a credit line to the material. If material is not included in the article's Creative Commons licence and your intended use is not permitted by statutory regulation or exceeds the permitted use, you will need to obtain permission directly from the copyright holder. To view a copy of this licence, visit http://creativecommons.org/licenses/by/4.0/. 


\section{Background}

For a patient with an acute red eye, two important diagnoses to consider are acute anterior uveitis (AAU) and bacterial keratitis. AAU and bacterial keratitis are both common and potentially sight threatening, and such patients need urgent referral to an ophthalmologist for management. Non-ophthalmologist physicians lack a test for early detection of AAU or bacterial keratitis and must rely on symptoms and plain signs, e.g. miosis, ciliary injection, or fluorescein-staining of an epithelial ulcer, which nevertheless can be subtle an easily missed. In consequence, symptoms and signs of AAU or bacterial keratitis may be misinterpreted as non-sight threatening external eye disease, delaying necessary referral to ophthalmologists.

Tear fluid is recognized as a potential source of biomarkers for a variety of diseases, both ocular and extraocular. Non-invasive sampling of tear fluid makes biomarkers more accessible than those of aqueous humor or vitreous. While most studies have focused on ocular surface biomarkers in dry eye or ocular allergic diseases $[11,26]$, biomarkers have also been proposed for intraocular diseases, such as diabetic retinopathy [17, 29]. In addition, biomarkers have been described for extraocular conditions, including multiple sclerosis and Parkinson's disease [3], thereby extending the potential usefulness of tear fluid biomarkers. There are relatively few studies on tear fluid biomarkers in uveitis $[4,7,19,22]$, but novel biomarkers were recently suggested for Behcet's disease and acute, non-infectious uveitis [18, 25]. Definite tear biomarkers for uveitis are yet to be established.

We have previously demonstrated that an inflammatory tear proteome profile involving the liver $\mathrm{X}$ receptor/ retinoid X receptor (LXR/RXR) pathway can be detected in patients with unilateral AAU using Schirmer's test strips [10]. In the current study, we explored the specificity of the upregulated tear proteins in unilateral AAU by comparing the tear proteome of eyes with unilateral AAU or bacterial keratitis with that of the unaffected eye and healthy controls.

\section{Methods}

\section{Patients}

The study took place at the Department of Ophthalmology at Oslo University Hospital, Norway. All subjects were examined by one of two trained ophthalmologists.

The AAU diagnosis was based on: 1) Symptoms: ocular pain and photophobia. 2) Signs: unilateral anterior chamber cells and ipsilateral anterior chamber flare, ciliary injection, and miosis. Exclusion criteria were: age < 18 years, pregnancy, bilateral AAU, intermediate-, posterior- or pan-uveitis, AAU secondary to suspected or known infectious disease, presence of any concurrent ocular disease (including dry eye syndrome, conjunctivitis, keratitis, eyelid disease, glaucoma, or neoplastic disease), prior severe ocular trauma, prior ocular surgery, intraocular pressure $<6$ or $>21 \mathrm{mmHg}$, use of topical eye medication, use of systemic anti-inflammatory medication, or smoking.

The diagnosis of bacterial keratitis was made clinically on the basis of: 1) a corneal epithelial defect confirmed by fluorescein staining and 2) a corneal infiltrate indicative of bacterial infection. Exclusion criteria were: age $<$ 18 years, pregnancy, presence of any ocular disease other than keratitis, prior significant ocular trauma, prior ocular surgery, ocular neoplastic disease, use of topical eye medications, use of systemic anti-inflammatory medication, or smoking.

Healthy controls were recruited among the staff at the Department of Ophthalmology. Exclusion criteria were: age $<18$ years, pregnancy, use of contact lenses, any current or prior ocular disease including dry eye or ocular allergy, prior significant ocular trauma, prior ocular surgery, use of topical eye medications, use of systemic anti-inflammatory medication, or smoking.

\section{Laser flare meter}

The degree of anterior chamber inflammation was quantified using a FM-600 laser flare meter (Kowa Company, Ltd., Tokyo, Japan). At least three valid and stable measurements were obtained per eye. Mean values, expressed in photon counts per millisecond ( $\mathrm{ph} / \mathrm{ms})$, were then automatically calculated by the laser flare meter software following exclusion of outliers.

\section{Tear fluid sampling}

We have previously described the method for using Schirmer's strips to collect and analyze tear fluid $[1,2$, 10]. Briefly, Schirmer's test strips were placed behind the lateral third portion of the lower eyelid for 5 minutes without anesthesia and with the eye closed. Test strips were then stored at $-140{ }^{\circ} \mathrm{C}$ until analyses. In the current study, two Schirmer's test strips were used for each eye. One strip was utilized for proteomics analysis, and the other was used for enzyme-linked immunosorbent assay (ELISA).

\section{Proteomics analysis}

Pooled samples from the affected eye in both patient groups were compared with pooled samples from healthy controls. In addition, pooled samples from affected eyes in the two patient groups were compared with pooled samples of the unaffected eyes in the same groups. Protein extraction and analyses were performed according to protocols described previously $[1,2]$. 


\section{Ingenuity pathway analysis}

Lists of protein identifiers (UniProt) generated by the proteomics analysis were uploaded onto the webdelivered application Ingenuity Pathways Analysis (IPA) (QIAGEN N.V., Venlo, Netherlands) and mapped to their corresponding gene objects/molecules. The lists of gene objects in IPA were then overlaid into the Ingenuity knowledge base, which contains a global molecular network, used to identify changes in pathways and biofunctions. Thereafter, biofunction analysis in IPA identified associated pathways and biofunctions on the basis of the ratio of the number of genes in the data set that were associated with the pathway/biofunction divided by the total number of genes that were associated with the pathway/biofunction. Fischer's Exact Test was used for statistical analysis to assess whether each pathway/biofunction was due to chance alone. The pathways/biofunctions that were represented with more molecules than expected by chance were reported.

\section{Enzyme-linked Immunosorbent assay}

On the basis of a previous study by our group [10], current results, and potential biological relevance, the acute-phase response protein Serpin Family A Member 3 (SERPINA3) was chosen for validation with ELISA. Tear fluid proteins were extracted from the second Schirmer's test strip, and the concentration of SERP INA3 was measured with a commercially available ELISA kit according to the manufacturer's instructions (Human SERPINA3 - product no RAB1687; Sigma Aldrich, St. Louis, MO, United States). Protein concentration measurements of SERPINA3 were performed in singlicate (because of low sample volumes) by a microplate absorbance reader (Victor $^{3}$; PerkinElmer, MA, United States). The concentration of SERPINA3 obtained from ELISA was normalized to total tear protein concentration. From here on the SERPINA3 concentration is expressed without its unit $([\mathrm{ng} / \mathrm{ml}] /$ total tear protein content $[\mu \mathrm{g} / \mu \mathrm{l}])$.

\section{Statistical analyses}

Statistical analyses were performed using Statistical Package for the Social Sciences (SPSS) version 25 (IBM Corp, Armonk, NY). Comparisons of three groups were performed using one-way analysis of variance (ANOVA) with Tukey's post-hoc test or Kruskal-Wallis H, followed by pairwise Mann-Whitney $U$ test for parametric and non-parametric data, respectively. Comparisons of two independent groups were done using Student's independent sample t-test for parametric data, while dependent groups were compared with Student's pairedsample t-test for parametric data and the Wilcoxon signed-rank test for non-parametric data. Chi-square test was used for comparison of categorical data. P-values < 0.05 were considered significant.

\section{Results}

\section{Patients}

The study included 13 patients with unilateral AAU and seven patients with bacterial keratitis. Fourteen staff members at the department served as healthy controls. The study groups were age- and sex-matched and displayed comparable ethnicity (Table 1 ). The mean duration of symptoms prior to tear sampling was slightly higher in the AAU group than in the bacterial keratitis group, but the difference was not significant. As

Table 1 Patient characteristics

\begin{tabular}{|c|c|c|c|c|}
\hline & Healthy control & Acute anterior uveitis & Bacterial keratitis & $P$-value \\
\hline $\mathrm{N}$ & 14 & 13 & 7 & - \\
\hline Age (years) & $41.1 \pm 11.6$ & $40.1 \pm 16.2$ & $40.2 \pm 15.3$ & $0.98^{a}$ \\
\hline Female/male & $9 / 5$ & $8 / 5$ & $5 / 2$ & $0.91^{b}$ \\
\hline Ethnicity (Caucasian/Asian/Hispanic/African) & $13 / 1 / 0 / 0$ & $11 / 1 / 1 / 0$ & $5 / 0 / 1 / 1$ & $0.38^{b}$ \\
\hline Duration of symptoms prior to tear fluid sampling (days) & $\mathrm{N} / \mathrm{A}$ & $4.8 \pm 3.6$ & $2.4 \pm 1.5$ & $0.13^{c}$ \\
\hline IOP in affected eye (mmHg) & $14.3 \pm 3.0^{*}$ & $10.7 \pm 2.4$ & $12.8 \pm 3.2$ & $0.008^{d}$ \\
\hline IOP in unaffected eye $(\mathrm{mmHg})$ & $14.3 \pm 3.0^{*}$ & $13.8 \pm 3.1$ & $12.0 \pm 2.5$ & $0.28^{a}$ \\
\hline Schirmer's test in affected eye (mm) & $13.4 \pm 8.8^{*}$ & $27.0 \pm 12.0$ & $16.3 \pm 11.0$ & $0.019^{e}$ \\
\hline Schirmer's test in unaffected eye (mm) & $13.4 \pm 8.8^{*}$ & $10.8 \pm 9.8$ & $7.7 \pm 1.2$ & $0.25^{f}$ \\
\hline Laser flare meter in affected eye (ph/ms) & $4.5 \pm 1.1^{*}$ & $170.5 \pm 175.7$ & $45.5 \pm 64.7$ & $<0.001^{\epsilon}$ \\
\hline Laser flare meter in unaffected eye (ph/ms) & $4.5 \pm 1.1^{*}$ & $4.4 \pm 2.8$ & $4.6 \pm 1.3$ & $0.98^{\mathrm{a}}$ \\
\hline HLA-B27 positive (number of patients) & - & $4^{9}$ & - & \\
\hline Bacteria identified in microbial culture (number of patients) & - & - & $6^{\text {h }}$ & \\
\hline
\end{tabular}

IOP Intraocular pressure, *Average of both eyes in healthy control; ${ }^{a}$ One-way analysis of variance (ANOVA); ${ }^{b}$ Chi-square; ${ }^{c}$ Mann-Whitney $\mathrm{U}$ test; ${ }^{\mathrm{d}}$ ANOVA followed by Tukey's post hoc test between patients with acute anterior uveitis and healthy control; ${ }^{\mathrm{e}}$ Kruskal-Wallis $\mathrm{H}$ test followed by pairwise Mann-Whitney $\mathrm{U}$ test between patients with acute anterior uveitis and healthy control; ${ }^{\mathrm{f}}$ Kruskal-Wallis $\mathrm{H}$ test; ${ }^{\mathrm{g}}$ one patient with ankylosing spondylitis, one patient with reactive arthritis; ${ }^{\mathrm{h}}$ S.aureus, S.epidermidis and P.acnes 
expected, intraocular pressure in the affected eyes of AAU patients was significantly lower than in the eyes of healthy controls. The Schirmer's test revealed higher tear secretion in the affected eyes of AAU patients compared with the eyes of healthy controls. Also, the mean laser flare value in the affected eyes of AAU patients was significantly higher than in the eyes of healthy controls.

\section{Tear fluid proteome in sick eyes versus healthy eyes}

For proteomics analysis, tear fluid samples were pooled from five different groups: 1) affected eyes of AAU patients, 2) unaffected eyes of AAU patients, 3) affected eyes of bacterial keratitis patients, 4) unaffected eyes of bacterial keratitis patients, and 5) eyes of healthy control. Relative protein ratios (between groups 1/2, 1/5, 3/4, and 3/5) were detected and calculated (as fold change) for a total of 272 unique proteins. Approximately one third of the tear fluid proteins that were increased in affected eyes of patients relative to unaffected eyes or eyes of healthy controls were overlapping between AAU and bacterial keratitis patients (Fig. 1).

Forty-four proteins were at least 1.5 -fold increased in the affected patient eyes relative to eyes of healthy controls. When comparing the affected patient eyes with the unaffected patient eyes, 46 proteins were at least 1.5 -fold increased. Table 2 summarizes the top 15 up-regulated proteins. Serum albumin concentration was decreased in tear fluid of affected patient eyes: - 1.34-fold decreased in affected eyes of AAU patients versus eyes of healthy controls; - 1.13-fold decreased in affected versus unaffected eye of AAU patients; - 1.07-fold decreased in affected eyes of bacterial keratitis patients versus eyes of healthy controls; and-1.23-fold decreased in affected versus unaffected eyes of bacterial keratitis patients.

\section{Ingenuity pathway analysis}

The top canonical pathways identified by IPA were comparable across all groups. Notably, the top three pathways affected in the affected eyes of both AAU and bacterial keratitis patients were acute phase response signaling, LXR/RXR activation, and FXR/RXR activation (Table 3).

The upstream regulator analysis used by IPA to detect potential transcriptional regulators yielded similar results when comparing AAU and bacterial keratitis patients with healthy controls (Table 4). Specifically, Tumor necrosis factor (TNF), Microtubule associated protein tau (MAPT), Amyloid beta precursor protein (APP), and Presenilin 1 (PSEN1) were identified as important transcriptional regulators in both AAU and bacterial keratitis patients relative to healthy controls. When comparing affected and unaffected eyes of AAU or bacterial keratitis patients, however, there were larger discrepancies in the lists of transcriptional regulators. In particular, lipopolysaccharide (LPS) was identified as an important transcriptional regulator for AAU patients.

The inflammatory profiles of the upregulated tear fluid proteins in the affected eyes of both AAU and bacterial keratitis patients were underscored by the identification of Inflammatory response among the top diseases and biofunctions for all compared groups (Table 5).

\section{Validation of SERPINA3 in tear fluid using enzyme-linked Immunosorbent assay}

Serpin Family A Member 3 was chosen for confirmatory ELISA analysis based on its potential biological relevance and results from a prior study by the research group [10]. The proteomic analysis of pooled tear fluid samples in the current study detected an increased level of SERP INA3 in the affected eyes of AAU (fold change: 1.78) and bacterial keratitis patients (fold change: 3.44 ) compared with the eyes of healthy controls. These results were reflected by the ELISA analysis, which demonstrated a slightly higher, yet non-significant, mean concentration of SERPINA3 in the affected eyes of AAU $(20.1 \pm 15.2)$ and bacterial keratitis patients $(33.5 \pm 50.2)$

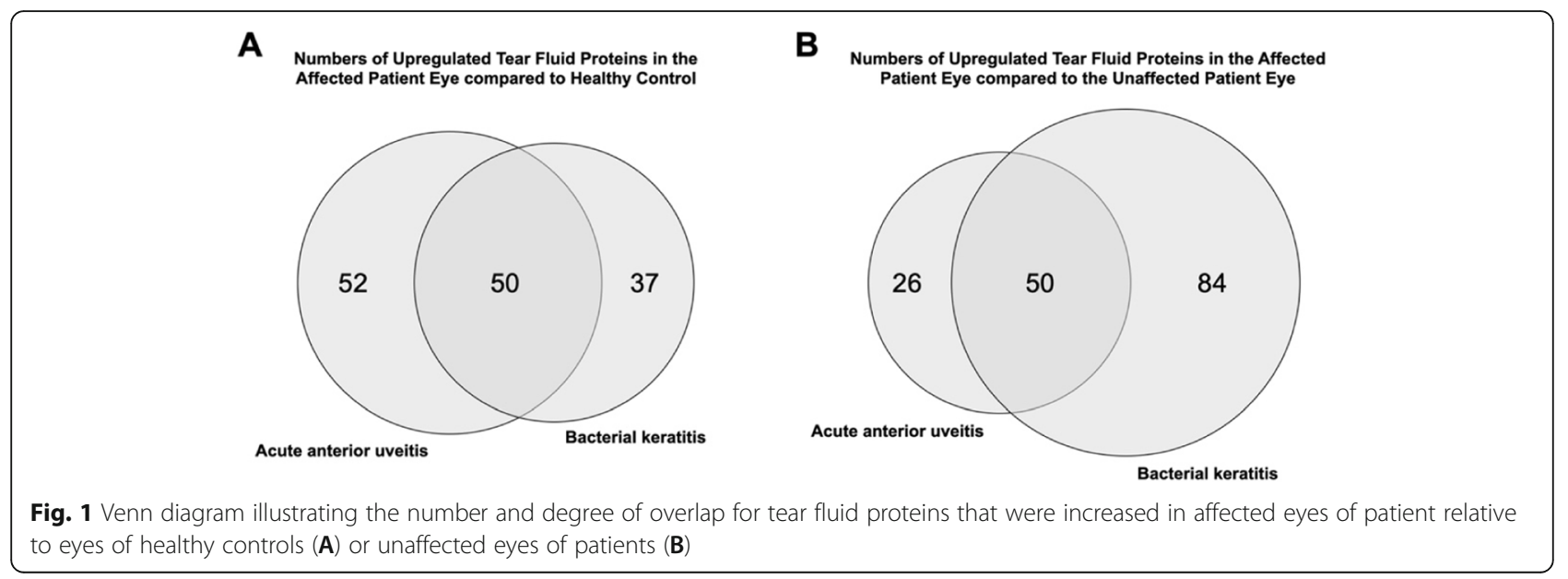


Table 2 Top 15 upregulated tear fluid protein level ratios

\begin{tabular}{|c|c|c|c|c|c|c|c|}
\hline \multicolumn{2}{|c|}{$\begin{array}{l}\text { Affected eyes of AAU patients } \\
\text { versus eyes of healthy controls }\end{array}$} & \multicolumn{2}{|c|}{$\begin{array}{l}\text { Affected versus unaffected } \\
\text { eye of AAU patients }\end{array}$} & \multicolumn{2}{|c|}{$\begin{array}{l}\text { Affected eyes of bacterial keratitis } \\
\text { patients versus eyes of healthy } \\
\text { controls }\end{array}$} & \multicolumn{2}{|c|}{$\begin{array}{l}\text { Affected versus unaffected eyes } \\
\text { of bacterial keratitis patients }\end{array}$} \\
\hline Name & Fold change & Name & Fold change & Name & Protein & Name & Fold change \\
\hline SMR3B & 8.4 & SMR3A & 10.7 & S100A9 & 7.6 & ORM2 & 14.1 \\
\hline SPARCL1 & 2.7 & CNDP2 & 5.2 & SERPINA3 & 3.4 & CST2 & 5.6 \\
\hline PRR27 & 2.4 & KRT4 & 5.0 & CXCL17 & 3.1 & CST5 & 4.7 \\
\hline ZG16B & 2.3 & CHI3L2 & 4.4 & APOC3 & 3.1 & CNDP2 & 3.4 \\
\hline EEF1A2 & 2.2 & CST5 & 4.1 & LXN & 3.0 & $\mathrm{FGB}$ & 2.7 \\
\hline MUC5AC & 2.1 & IGHV1-69D & 3.1 & S100P & 2.9 & RARRES1 & 2.7 \\
\hline SMR3A & 2.1 & LTF & 2.9 & NDST1 & 2.6 & CST1 & 2.6 \\
\hline LPO & 2.0 & KRT13 & 2.6 & $\mathrm{~A} 2 \mathrm{M}$ & 2.4 & OPRPN & 2.5 \\
\hline CALU & 2.0 & OPRPN & 2.4 & CD22 & 2.3 & FGG & 2.4 \\
\hline CST2 & 1.9 & KRT19 & 2.3 & SMR3A & 2.1 & FGA & 2.3 \\
\hline SCGB2A1 & 1.9 & SERPIND1 & 2.1 & ZG16B & 2.1 & KRT19 & 2.3 \\
\hline OPRPN & 1.9 & APOA 1 & 2.1 & CST2 & 2.1 & KRT13 & 2.2 \\
\hline SERPINA3 & 1.8 & CTSD & 2.0 & IGKV3D-11 & 1.9 & KRT4 & 2.2 \\
\hline MYL12B & 1.7 & SCGB2A1 & 1.9 & PLA2G2A & 1.9 & ANXA1 & 2.1 \\
\hline ANXA3 & 1.6 & FGG & 1.9 & CALU & 1.8 & KRT7 & 2.1 \\
\hline
\end{tabular}

$A A U$ acute anterior uveitis

compared with the eyes of healthy controls $(18.4 \pm 12.4)$ (Fig. 2a). However, the increased mean SERPINA3 concentration in the affected eyes of bacterial keratitis patients was due to one extreme outlier (Fig. 2a). If this value had been omitted from the analysis, the mean SERPINA3 would have been lower than for healthy controls (data not shown).

The proteomics analysis demonstrated a slightly decreased level of SERPINA3 in the affected eyes relative to the unaffected eyes of AAU patients (fold change: 1.04). In bacterial keratitis patients, by contrast, the SERPINA3 level was higher in the affected eyes relative to the unaffected eyes (fold change: 2.04). Similar tendencies were seen in the ELISA analysis, in which SERP INA3 was significantly decreased in the affected eyes $(20.1 \pm 15.2)$ compared with the unaffected eyes $(37.0 \pm$ 19.3; $P=0.009$ ) of AAU patients (Fig. 2a and b). In bacterial keratitis patients, the mean SERPINA3 concentration was increased in the affected eyes $(33.5 \pm 50.2)$ compared with the unaffected eyes $(25.0 \pm 19.4)$ (Fig. 2a and $b$ ).

The concentration of SERPINA3 in the unaffected eyes of AAU patients was significantly higher than in the eyes of healthy controls $(P=0.019)$ (Fig. $2 b)$. By contrast, the

Table 3 Top canonical pathways

\begin{tabular}{|c|c|c|c|c|c|c|c|}
\hline \multirow{2}{*}{$\begin{array}{l}\text { Affected eyes of AAU patients versus } \\
\text { eyes of healthy controls } \\
\text { Name }\end{array}$} & \multicolumn{2}{|c|}{$\begin{array}{l}\text { Affected versus unaffected } \\
\text { eye of } A A U \text { patients }\end{array}$} & \multicolumn{2}{|c|}{$\begin{array}{l}\text { Affected eyes of bacterial } \\
\text { keratitis patients versus } \\
\text { eyes of healthy controls }\end{array}$} & \multicolumn{3}{|c|}{$\begin{array}{l}\text { Affected versus unaffected eyes of } \\
\text { bacterial keratitis patients }\end{array}$} \\
\hline & $\begin{array}{l}P \text { - } \\
\text { value }\end{array}$ & Name & $\begin{array}{l}P \text { - } \\
\text { value }\end{array}$ & Name & $\begin{array}{l}P- \\
\text { value }\end{array}$ & Name & $\begin{array}{l}P \text { - } \\
\text { value }\end{array}$ \\
\hline Acute phase response signaling & $\begin{array}{l}1.07 \mathrm{E}- \\
26\end{array}$ & LXR/RXR activation & $\begin{array}{l}2.80 \mathrm{E}- \\
28\end{array}$ & LXR/RXR activation & $\begin{array}{l}6.85 \mathrm{E}- \\
25\end{array}$ & LXR/RXR activation & $\begin{array}{l}3.20 \mathrm{E}- \\
29\end{array}$ \\
\hline LXR/RXR activation & $\begin{array}{l}6.50 \mathrm{E}- \\
26\end{array}$ & FXR/RXR activation & $\begin{array}{l}8.72 \mathrm{E}- \\
28\end{array}$ & FXR/RXR activation & $\begin{array}{l}1.84 \mathrm{E}- \\
24\end{array}$ & FXR/RXR activation & $\begin{array}{l}1.05 \mathrm{E}- \\
28\end{array}$ \\
\hline FXR/RXR activation & $\begin{array}{l}1.9 \mathrm{E}- \\
25\end{array}$ & $\begin{array}{l}\text { Acute phase response } \\
\text { signaling }\end{array}$ & $\begin{array}{l}1.11 \mathrm{E}- \\
27\end{array}$ & $\begin{array}{l}\text { Acute phase response } \\
\text { signaling }\end{array}$ & $\begin{array}{l}7.90 \mathrm{E}- \\
21\end{array}$ & $\begin{array}{l}\text { Acute phase response } \\
\text { signaling }\end{array}$ & $\begin{array}{l}2.05 \mathrm{E}- \\
28\end{array}$ \\
\hline Clathrin-mediated endocytosis signaling & $\begin{array}{l}3.97 \mathrm{E}- \\
12\end{array}$ & Coagulation system & $\begin{array}{l}5.86 \mathrm{E}- \\
13\end{array}$ & $\begin{array}{l}\text { Glucocorticoid } \\
\text { receptor signaling }\end{array}$ & $\begin{array}{l}1.69 \mathrm{E}- \\
11\end{array}$ & Coagulation system & $\begin{array}{l}9.63 \mathrm{E}- \\
13\end{array}$ \\
\hline Atherosclerosis signaling & $\begin{array}{l}4.51 \mathrm{E}- \\
11\end{array}$ & $\begin{array}{l}\text { Glucocorticoid } \\
\text { receptor signaling }\end{array}$ & $\begin{array}{l}5.61 \mathrm{E}- \\
11\end{array}$ & Glycolysis I & $\begin{array}{l}2.86 \mathrm{E}- \\
11\end{array}$ & $\begin{array}{l}\text { Glucocorticoid } \\
\text { receptor signaling }\end{array}$ & $\begin{array}{l}3.99 \mathrm{E}- \\
11\end{array}$ \\
\hline
\end{tabular}


Table 4 Top upstream regulators

\begin{tabular}{|c|c|c|c|c|c|c|c|}
\hline \multicolumn{2}{|c|}{$\begin{array}{l}\text { Affected eyes of AAU } \\
\text { patients versus eyes of } \\
\text { healthy controls }\end{array}$} & \multirow{2}{*}{$\begin{array}{l}\text { Affected versus unaffected eyes of AAU patients } \\
\text { Name }\end{array}$} & \multicolumn{3}{|c|}{$\begin{array}{l}\text { Affected eyes of bacterial keratitis } \\
\text { patients versus eyes of healthy } \\
\text { controls }\end{array}$} & \multicolumn{2}{|c|}{$\begin{array}{l}\text { Affected versus } \\
\text { unaffected eyes of } \\
\text { bacterial keratitis } \\
\text { patients }\end{array}$} \\
\hline Name & $p$-value & & $p$-value & Name & $p$-value & Name & $p$-value \\
\hline MAPT & $2.25 E-26$ & Lipopolysaccharide & $5.74 \mathrm{E}-31$ & MAPT & $2.82 \mathrm{E}-25$ & MAPT & 2.91E-22 \\
\hline APP & $2.90 \mathrm{E}-23$ & Nitrofurantoin & $2.14 \mathrm{E}-30$ & APP & $1.69 \mathrm{E}-22$ & APP & $6.12 \mathrm{E}-20$ \\
\hline TNF & $2.42 \mathrm{E}-18$ & Dexamethasone & $6.35 E-26$ & PSEN1 & $1.32 \mathrm{E}-18$ & TNF & $1.82 \mathrm{E}-17$ \\
\hline TP53 & $1.54 \mathrm{E}-17$ & Beta-estradiol & $1.21 \mathrm{E}-23$ & TGFß1 & $2.21 \mathrm{E}-17$ & TGFß1 & 3.99E-17 \\
\hline PSEN1 & $2.24 \mathrm{E}-17$ & APP & 4.26E-21 & TNF & 4.41E-17 & IL6 & $1.73 \mathrm{E}-16$ \\
\hline
\end{tabular}

$A A U$ acute anterior uveitis

concentration of SERPINA3 in the unaffected eyes of bacterial keratitis patients did not significantly differ from the eyes of healthy controls (Fig. 2b).

In summary, the ELISA results of the relative abundance of SERPINA3 between affected and unaffected eyes of patients, as well as between patients and healthy controls, corresponded to the proteomics results.

We also compared tear concentration of SERPINA3 in AAU patients that were HLA-B27 positive $(N=4)$ with those who were negative $(N=3)$. There were no significant differences in SERPINA3 concentration when comparing affected eyes of HLA-B27 positive patients $(24.5 \pm 23.3)$ with affected eyes of HLA-B27 negative patients $(18.6 \pm 11.5 ; P=0.68)$. Similarly, SERPINA3 concentration in unaffected eyes of HLA-B27 positive patients $(42.8 \pm 14.0)$ did not differ significantly from unaffected eyes of HLA-B27 negative patients $(37.4 \pm 31$. $P=0.76$ ).

We also assessed the relationship between the concentration of SERPINA3 in the unaffected eyes of AAU patients with laser flare meter measurements of the affected eyes of the same patients. Following curvefitting a significant logarithmic relationship was found; the SERPINA3 concentration appeared to increase relatively rapidly at the lower spectrum of flare values, before leveling off at the higher spectrum $(P=0.022)$ (Fig. 3a). Thus, concentration of SERPINA3 in the unaffected eyes of AAU patients appears to be related to the level of inflammation as measured by laser flare meter in the affected eye.

Since the concentration of SERPINA3 in the unaffected eye of AAU patients was significantly higher than in the eyes of healthy controls, we explored to which extent the measurement of SERPINA3 could be used as a biomarker for unilateral AAU. A receiver operating characteristic (ROC) curve was calculated to estimate sensitivity and specificity of a given cutoff value for SERPINA3 concentration in tear fluid (Fig. $3 \mathrm{~b})$. The ROC curve analysis demonstrated an acceptable and significant area under the curve (AUC: $0.764 ; P=0.011$ ). Optimal sensitivity of $85 \%$ and specificity of $71 \%$ were obtained by using $>26$ as cutoff for SERPINA3 concentration. Consequently, measurement of SERPINA3 in tear fluid can potentially discriminate between AAU and non-AAU patients in the current study.

Table 5 Top diseases and bio functions - diseases and disorders

\begin{tabular}{|c|c|c|c|c|c|c|c|}
\hline \multicolumn{2}{|c|}{$\begin{array}{l}\text { Affected eyes of AAU patients } \\
\text { versus eyes of healthy controls }\end{array}$} & \multicolumn{2}{|c|}{$\begin{array}{l}\text { Affected versus unaffected eyes } \\
\text { of AAU patients }\end{array}$} & \multicolumn{2}{|c|}{$\begin{array}{l}\text { Affected eyes of bacterial } \\
\text { keratitis patients versus eyes of } \\
\text { healthy controls }\end{array}$} & \multicolumn{2}{|c|}{$\begin{array}{l}\text { Affected versus unaffected eyes } \\
\text { of bacterial keratitis patients }\end{array}$} \\
\hline Name & $p$-value & Name & $p$-value & Name & $p$-value & Name & $p$-value \\
\hline Inflammatory response & $\begin{array}{l}7.17 \mathrm{E}-06- \\
1.24 \mathrm{E}-45\end{array}$ & $\begin{array}{l}\text { Inflammatory } \\
\text { response }\end{array}$ & $\begin{array}{l}4.76 \mathrm{E}-06- \\
1.04 \mathrm{E}-45\end{array}$ & Inflammatory response & $\begin{array}{l}3.46 \mathrm{E}-05- \\
2.65 \mathrm{E}-42\end{array}$ & Inflammatory response & $\begin{array}{l}1.28 \mathrm{E}-05- \\
1.52 \mathrm{E}-46\end{array}$ \\
\hline $\begin{array}{l}\text { Organismal injury and } \\
\text { abnormalities }\end{array}$ & $\begin{array}{l}7.34 \mathrm{E}-06- \\
1.69 \mathrm{E}-28\end{array}$ & Neurological disease & $\begin{array}{l}2.76 \mathrm{E}-06- \\
1.18 \mathrm{E}-35\end{array}$ & $\begin{array}{l}\text { Organismal injury and } \\
\text { abnormalities }\end{array}$ & $\begin{array}{l}3.46 \mathrm{E}-05- \\
2.01 \mathrm{E}-28\end{array}$ & $\begin{array}{l}\text { Organismal injury and } \\
\text { abnormalities }\end{array}$ & $\begin{array}{l}1.63 \mathrm{E}-05- \\
6.31 \mathrm{E}-28\end{array}$ \\
\hline $\begin{array}{l}\text { Dermatological } \\
\text { diseases and } \\
\text { conditions }\end{array}$ & $\begin{array}{l}7.17 \mathrm{E}-06- \\
5.17 \mathrm{E}-28\end{array}$ & $\begin{array}{l}\text { Organismal injury } \\
\text { and abnormalities }\end{array}$ & $\begin{array}{l}4.76 \mathrm{E}-06- \\
1.18 \mathrm{E}-35\end{array}$ & $\begin{array}{l}\text { Dermatological } \\
\text { diseases and } \\
\text { conditions }\end{array}$ & $\begin{array}{l}2.01 \mathrm{E}-05- \\
3.20 \mathrm{E}-23\end{array}$ & $\begin{array}{l}\text { Dermatological } \\
\text { diseases and } \\
\text { conditions }\end{array}$ & $\begin{array}{l}9.09 \mathrm{E}-06- \\
1.14 \mathrm{E}-27\end{array}$ \\
\hline $\begin{array}{l}\text { Endocrine system } \\
\text { disorders }\end{array}$ & $\begin{array}{l}2.44 \mathrm{E}-08- \\
2.82 \mathrm{E}-26\end{array}$ & $\begin{array}{l}\text { Endocrine system } \\
\text { disorders }\end{array}$ & $\begin{array}{l}1.05 \mathrm{E}-08- \\
6.43 \mathrm{E}-29\end{array}$ & Metabolic disease & $\begin{array}{l}2.90 \mathrm{E}-05- \\
2.46 \mathrm{E}-21\end{array}$ & Metabolic disease & $\begin{array}{l}2.78 \mathrm{E}-06- \\
1.22 \mathrm{E}-23\end{array}$ \\
\hline Metabolic disease & $\begin{array}{l}3.10 \mathrm{E}-06- \\
7.93 \mathrm{E}-25\end{array}$ & Metabolic disease & $\begin{array}{l}3.15 \mathrm{E}-06- \\
2.43 \mathrm{E}-27\end{array}$ & $\begin{array}{l}\text { Endocrine system } \\
\text { disorders }\end{array}$ & $\begin{array}{l}3.07 \mathrm{E}-05- \\
6.38 \mathrm{E}-20\end{array}$ & Neurological disease & $\begin{array}{l}1.37 \mathrm{E}-05- \\
3.58 \mathrm{E}-21\end{array}$ \\
\hline
\end{tabular}

$A A U$ acute anterior uveitis 

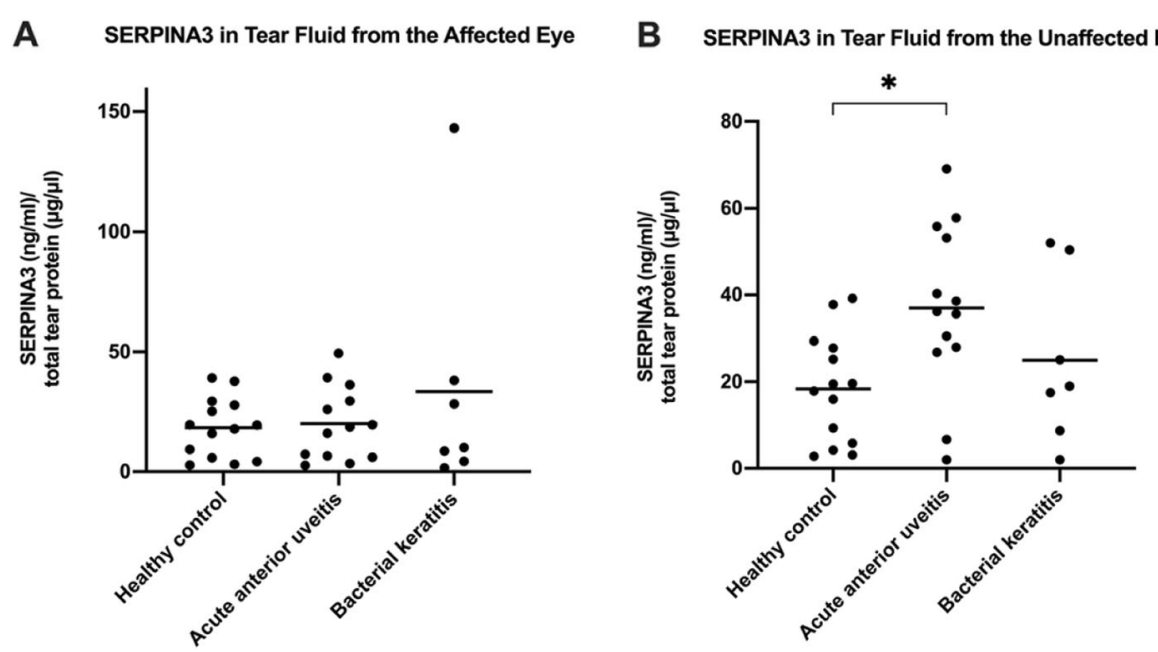

Fig. 2 Serpin Family A Member 3 (SERPINA3) was measured in tear fluid of the affected eye (A) and unaffected eye (B) by enzyme-linked immunosorbent assay in patients with unilateral acute anterior uveitis and bacterial keratitis and in healthy controls. Individual patient values are plotted together with mean values (horizontal lines). ${ }^{*} P=0.019$

\section{Discussion}

The current study demonstrated an increased concentration of SERPINA3 by ELISA in tear fluid of the unaffected eyes of patients with unilateral AAU compared with healthy controls. Hence, there is a rationale for exploring the tear fluid proteome of apparently healthy eyes in clinically unilateral conditions. In addition, an inflammatory tear fluid protein profile was shown by proteomics in patients with both AAU and bacterial keratitis.

Patients and healthy control in this study were comparable in terms of age, sex, and ethnicity. A slightly reduced intraocular pressure in AAU patients likely did not affect results significantly. Reduced intraocular pressure in AAU may be the result of either decreased aqueous humor production or increased uveoscleral outflow [28]. Tear secretion, however, varied considerably, being highest in affected eyes of AAU patients. Tear secretion can be classified as basal, stimulated, emotional, and closed-eyes tears [13]. In addition, tear proteins have been termed constitutive (i.e. produced at a constant level), regulated (i.e. their production rate change with level of tear secretion), and serum derived (which decrease whenever tear secretion increases) [9]. For example, in stimulated tear secretion the concentration of the serum protein albumin can decrease to
A

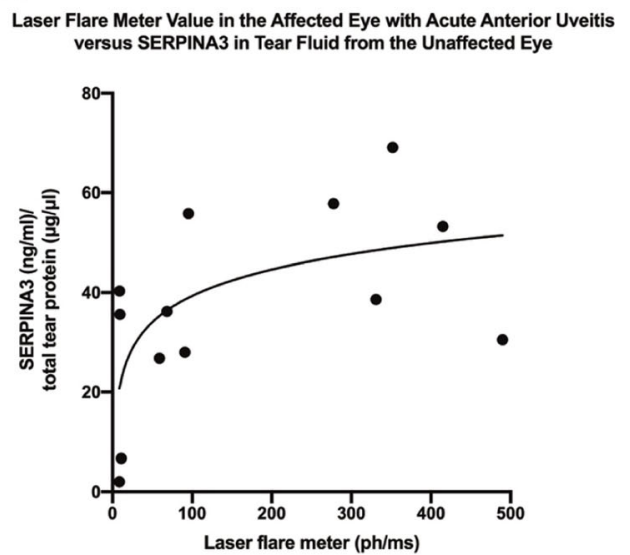

$B$ ROC Curve for Diagnostic use of SERPINA3 in Tear Fluid
from the Unaffected Eye of Acute Anterior Uveitis Patients

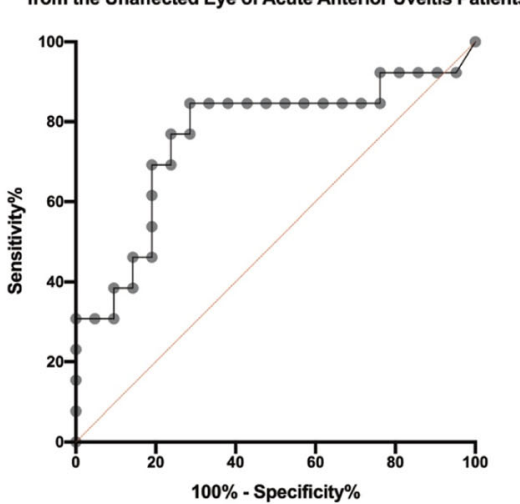

Fig. 3 Serpin Family A Member 3 (SERPINA3) was measured by enzyme-linked immunosorbent assay in tear fluid of the unaffected eyes of patients with unilateral acute anterior uveitis and compared with laser flare meter measurements of anterior chamber inflammation of the affected eyes (A). Individual patient values are plotted together with the best fitting logarithmic model (curve) $\left(R^{2}=0.39 ; P=0.022\right)$. B A receiver operating characteristic (ROC) curve was calculated to estimate sensitivity and specificity of varying cutoff values for SERPINA3 concentration for detecting patients with unilateral acute anterior uveitis (area under the curve: 0.764; $P=0.011$ ) 
approximately one fifth of the concentration compared to that of unstimulated tear secretion [14]. Other tear proteins, including lactoferrin and lipocalin-1, do not change considerably with the level of tear secretion [13]. Therefore, the type of tear secretion exhibited at the time of tear sampling will affect the composition of tears. In our study, the patients with AAU had more than twice as high Schirmer's test score compared to the healthy controls. Moreover, the concentration of serum albumin in tear samples from the affected eyes of AAU patients was lower than in the contralateral unaffected eyes and also lower than in eyes of healthy controls. Consequently, for AAU patients, these results could indicate a reduced concentration of serum-derived proteins in tear fluid from the affected eyes due to stimulated tear secretion.

Approximately one third of tear proteins that were increased in the patients relative to the healthy controls were shared between AAU and bacterial keratitis patients. Hence, although both patient populations displayed ocular inflammation, there were considerable differences in which proteins were increased. For AAU patients, the strongest increase in concentration was seen for submaxillary gland androgen regulated protein $3 \mathrm{~B}$ (SMR3B) and submaxillary gland androgen regulated protein $3 \mathrm{~A}$ (SMR3A). As SMR3A was increased both compared to eyes of healthy controls and unaffected eyes of patients, this protein was likely produced locally and not serumderived. The submaxillary gland androgen regulated proteins have been suggested to belong to a new class of antiinflammatory agents [21]. These proteins have been shown to especially target neutrophils through inhibition of chemotaxis and superoxide production [21]. They have also been demonstrated to protect against LPS-induced shock [20, 21]. Interestingly, our results identified LPS, an inducer of endotoxin-induced uveitis (EIA) [23], as the top upstream regulator in affected eyes of AAU compared with the contralateral unaffected eye.

For patients with bacterial keratitis, the two top upregulated tear proteins were $\mathrm{S} 100$ calcium-binding protein A9 (S100A9) and orosomucoid 2 (ORM2), compared with eyes of healthy controls and unaffected eyes of patients, respectively. S100A9 joins S100A8 to form calprotectin, which is highly specific to neutrophils [30]. The quantification of calprotectin in stool is an established biomarker of inflammatory bowel disease, and the protein correlates with the number of neutrophils present in the bowel [24]. Hence, it appears sound that S100A9 is increased in tear fluid of patients with bacterial keratitis. Orosomucoid, also termed alpha-1-acid glycoprotein, is one of the major acute phase proteins in humans, and it exerts immunomodulatory effects [16]. In unilateral Behcet's disease, alpha-1-acid glycoprotein 1 was increased in tears of the affected eye compared with the contralateral unaffected eye [18]. Orosomucoid is mainly produced by hepatocytes in the liver, but extra-hepatic production sites including leukocytes have also been acknowledged [12]. Hence, ORM2 may have been secreted by local corneal leukocytes; we found high levels of this protein in the affected eyes of patients with bacterial keratitis compared with the unaffected, contralateral eyes.

In accordance with our prior pilot study of AAU patients [10], LXR/RXR activation was among the top canonical pathways activated in AAU patients in the current study. However, because activation of this pathway was also evident in patients with bacterial keratitis, it was not specific for AAU. Furthermore, three of the top five canonical pathways identified were shared between AAU and bacterial keratitis patients.

Serpin Family A Member 3 was increased in the unaffected eyes of patients with unilateral AAU compared with healthy controls. Serpin Family A Member 3 can be induced by interleukin-1 (IL1), IL6, and probably also by the JAK/STAT-pathway [5]. Interleukin-1 and 6 are important cytokines in the pathogenesis of uveitis, and increased levels of these cytokines were found in the aqueous humor of patients with idiopathic and HLAB27-related anterior uveitis [8]. Expression of SERPINA3 mRNA has been detected in the iris and ciliary body following LPS-injection in rats [27], as well as in a number of other tissues throughout the body [5]. However, our laser flare measurements indicated absence of anterior chamber inflammation in the unaffected eye of the AAU patients, suggesting that local production of SERPINA3 was unlikely. Serpin Family A Member 3 is considered to be produced by the liver and enter the blood stream as an acute phase response protein [5]. Hence, SERP INA3 in the AAU patients most likely represents a primarily serum-derived tear fluid protein. This would explain the lower concentration of SERPINA3 in the affected eyes, which displayed hypersecretion of tears that normally decreases the concentration of serumderived tear proteins. In a prior study, serum levels of another acute phase protein, alpha-1-acid glycoprotein (also termed ORM), was related to the severity of inflammation in patients with idiopathic AAU [15]. A recent study suggested that the acute phase response protein c-reactive protein (CRP) in serum could be an indicator of the degree of inflammation in anterior uveitis [6]. This finding is in accordance with our study, in which SERPINA3 was correlated with the degree of anterior chamber flare in the affected eyes of AAU patients.

\section{Conclusions}

In conclusion, the current study demonstrated an increased tear fluid concentration of the acute phase 
response protein SERPINA3 in patients with unilateral AAU compared with healthy controls. To further explore the potential of SERPINA3 as a biomarker, future studies should assess its dynamic properties in tear fluid in active and quiescent uveitis.

\section{Abbreviations}

AAU: Acute anterior uveitis; ANOVA: Analysis of variance; APP: Amyloid beta precursor protein; AUC: Area under the curve; CRP: C-reactive protein; EIA: Endotoxin-induced uveitis; ELISA: Enzyme-linked immunosorbent assay; FXR/RXR: Farnesoid X receptor/retinoid X receptor; IL1: Interleukin-1; IL6: Interleukin-6; IOP: Intraocular pressure; IPA: Ingenuity Pathways Analysis; JAK/STAT: Janus kinase/signal transducer and activator of transcription; LPS: Lipopolysaccharide; LXR/RXR: Liver X receptor/retinoid X receptor; MAPT: Microtubule associated protein tau; ORM2: Orosomucoid 2; PSEN1: Presenilin 1; ROC: Receiver operating characteristic; S100A8: S100 calcium-binding protein A8; S100A9: S100 calcium-binding protein A9; SERP INA3: Serpin Family A Member 3; SMR3A: Submaxillary gland androgen regulated protein $3 \mathrm{~A}$; SMR3B: Submaxillary gland androgen regulated protein 3B; TNF: Tumor necrosis factor

\section{Acknowledgements}

The authors thank Kari Julien for contributing on the ELISA analysis.

\section{Authors' contributions}

JRE and MA examined the patients and collected tear samples. MP analyzed the tear samples with proteomics and ELISA. JRE and OKO performed IPA. $\varnothing K$, MCM and GP participated in the critical revision and correction of the manuscript. All authors read and approved the final manuscript.

\section{Funding}

The study was funded by The Norwegian Association of the Blind and Partially Sighted, The Olav Raagholt and Gerd Meidel Raagholt Research Foundation, Arthur og Odd Clausons Legat and Department of Innovation at Oslo University Hospital.

\section{Availability of data and materials}

The datasets used and/or analyzed during the current study are available from the corresponding author on reasonable request.

\section{Declarations}

\section{Ethics approval and consent to participate}

The study (project number 2017/345) was approved by the Regional Committees for Medical and Health Research Ethics in Norway and adhered to the tenets of the Declaration of Helsinki. Written informed consent was obtained from all subjects.

\section{Consent for publication}

Written informed consent was obtained from all subjects.

\section{Competing interests}

The authors report no competing interests.

\section{Author details \\ 'Department of Ophthalmology, Center for Eye Research, Oslo University Hospital and University of Oslo, Oslo, Norway. ${ }^{2}$ Department of Medical Biochemistry, Blood Cell Research Group, Section for Research, Oslo University Hospital, Oslo, Norway. ${ }^{3}$ Department of Medical Biochemistry, Hormone Laboratory, Oslo University Hospital, Oslo, Norway.}

Received: 21 September 2020 Accepted: 28 May 2021 Published online: 02 July 2021

\section{References}

1. Aass C, Norheim I, Eriksen EF, Bornick EC, Thorsby PM, Pepaj M (2016) Comparative proteomic analysis of tear fluid in Graves' disease with and without orbitopathy. Clin Endocrinol 85(5):805-812. https://doi.org/10.1111/ cen.13122
2. Aass C, Norheim I, Eriksen EF, Thorsby PM, Pepaj M (2015) Single unit filteraided method for fast proteomic analysis of tear fluid. Anal Biochem 480:15. https://doi.org/10.1016/j.ab.2015.04.002

3. Abreu CM, Soares-Dos-Reis R, Melo PN, Relvas JB, Guimaraes J, Sa MJ, Cruz AP, Mendes Pinto I (2018) Emerging biosensing Technologies for Neuroinflammatory and Neurodegenerative Disease Diagnostics. Front Mol Neurosci 11:164. https://doi.org/10.3389/fnmol.2018.00164

4. Angeles-Han ST, Yeh S, Patel P, Duong D, Jenkins K, Rouster-Stevens KA, Altaye M, Fall N, Thornton S, Prahalad S, Holland GN (2018) Discovery of tear biomarkers in children with chronic non-infectious anterior uveitis: a pilot study. J Ophthalmic Inflam Infect 8(1):17. https://doi.org/10.1186/s1234 8-018-0156-5

5. Baker C, Belbin O, Kalsheker N, Morgan K (2007) SERPINA3 (aka alpha-1antichymotrypsin). Front Biosci 12(8-12):2821-2835. https://doi.org/10.2 $741 / 2275$

6. Bozkurt E, Muhafiz E, Sengul D, Ucak T, Atum M (2020) Can the CRP/ albumin Ratio be used as a new indicator of activation in patients with Uveitis? Ocul Immunol Inflamm:1-6. https://doi.org/10.1080/09273948.202 0.1714061

7. Carreno E, Portero A, Herreras JM, Garcia-Vazquez C, Whitcup SM, Stern ME, Calonge M, Enriquez-de-Salamanca A (2017) Cytokine and chemokine tear levels in patients with uveitis. Acta Ophthalmol 95(5):e405-e414. https://doi. org/10.1111/aos.13292

8. Chen W, Zhao B, Jiang R, Zhang R, Wang Y, Wu H, Gordon L, Chen L (2015) Cytokine expression profile in aqueous humor and sera of patients with acute anterior uveitis. Curr Mol Med 15(6):543-549. https://doi.org/10.2174/1 566524015666150731100012

9. Craig JP, Willcox MD, Argueso P, Maissa C, Stahl U, Tomlinson A, Wang J, Yokoi N, Stapleton F, members of TIWOCLD (2013) The TFOS international workshop on contact lens discomfort: report of the contact lens interactions with the tear film subcommittee. Invest Ophthalmol Vis Sci 54(11):TFOS123-TFOS156. https://doi.org/10.1167/iovs.13-13235

10. Eidet JR, Jorstad OK, Fostad IG, Olstad OK, Sorland RO, Moe MC, Petrovski G, Pepaj M (2020) Unilateral acute anterior uveitis is associated with ipsilateral changes in the tear fluid proteome that involves the LXR/RXR pathway. J Ophthalmic Inflam Infect 10(1):13. https://doi.org/10.1186/s12348-020-002 04-4

11. Fong PY, Shih KC, Lam PY, Chan TCY, Jhanji V, Tong L (2019) Role of tear film biomarkers in the diagnosis and management of dry eye disease. Taiwan J Ophthalmol 9(3):150-159. https://doi.org/10.4103/tjo.tjo_56_19

12. Fournier T, Medjoubi NN, Porquet D (2000) Alpha-1-acid glycoprotein. Biochim Biophys Acta 1482(1-2):157-171. https://doi.org/10.1016/s0167-483 8(00)00153-9

13. Fullard RJ, Snyder C (1990) Protein levels in nonstimulated and stimulated tears of normal human subjects. Invest Ophthalmol Vis Sci 31(6):1119-1126

14. Fullard RJ, Tucker DL (1991) Changes in human tear protein levels with progressively increasing stimulus. Invest Ophthalmol Vis Sci 32(8):2290-2301

15. Gupta AK, Sarin GS, Rastogi A, Grover AK, Pandey PK (1991) Serum alpha-1 acid glycoprotein levels in acute idiopathic anterior uveitis. Ann Ophthalmol 23(11):406-409

16. Hochepied T, Berger FG, Baumann H, Libert C (2003) Alpha (1)-acid glycoprotein: an acute phase protein with inflammatory and immunomodulating properties. Cytokine Growth Factor Rev 14(1):25-34. https://doi.org/10.1016/s1359-6101(02)00054-0

17. Kastelan S, Oreskovic I, Biscan F, Kastelan H, Gverovic Antunica A (2020) Inflammatory and angiogenic biomarkers in diabetic retinopathy. Biochem med (Zagreb) 30 (3):030502. Doi:https://doi.org/10.11613/BM.2020.030502

18. Liang A, Qin W, Zhang M, Gao F, Zhao C, Gao Y (2020) Profiling tear proteomes of patients with unilateral relapsed Behcet's disease-associated uveitis using data-independent acquisition proteomics. PeerJ 8:e9250. https://doi.org/10.7717/peerj.9250

19. Lynch Ml, Cordeiro F, Ferreira S, Ximenes R, Orefice F, Malagueno E (2004) Lacrimal secretory IgA in active posterior uveitis induced by toxoplasma gondii. Mem Inst Oswaldo Cruz 99(8):861-864. https://doi.org/10.1590/ s0074-02762004000800013

20. Mathison RD, Befus AD, Davison JS (1997) A novel submandibular gland peptide protects against endotoxic and anaphylactic shock. Am J Phys 273(3 Pt 2):R1017-R1023. https://doi.org/10.1152/ajpregu.1997.273.3.R1017

21. Mathison RD, Davison JS, Befus AD, Gingerich DA (2010) Salivary gland derived peptides as a new class of anti-inflammatory agents: review of preclinical pharmacology of C-terminal peptides of SMR1 protein. J Inflamm 7(1):49. https://doi.org/10.1186/1476-9255-7-49 
22. Mirza GE, Karakucuk S, Er M, Gungormus N, Karakucuk I, Saraymen R (2001) Tear nitrite and nitrate levels as nitric oxide end products in patients with Behcet's disease and non-Behcet's uveitis. Ophthalmic Res 33(1):48-51. https://doi.org/10.1159/000055641

23. Rosenbaum JT, McDevitt HO, Guss RB, Egbert PR (1980) Endotoxin-induced uveitis in rats as a model for human disease. Nature 286(5773):611-613. https://doi.org/10.1038/286611a0

24. Roseth AG, Schmidt PN, Fagerhol MK (1999) Correlation between faecal excretion of indium-111-labelled granulocytes and calprotectin, a granulocyte marker protein, in patients with inflammatory bowel disease. Scand J Gastroenterol 34(1):50-54. https://doi.org/10.1080/00365529950172 835

25. Shirinsky IV, Biryukova AA, Kalinovskaya NY, Shirinsky VS (2020) Tear cytokines as potential biomarkers in non-infectious uveitis: post hoc analysis of a randomised clinical trial. Graefes Arch Clin Exp Ophthalmol 258(8): 1813-1819. https://doi.org/10.1007/s00417-020-04707-7

26. Shoji I (2020) Ocular allergy test and biomarkers on the ocular surface: clinical test for evaluating the ocular surface condition in allergic conjunctival diseases. Allergol Int 69(4):496-504. https://doi.org/10.1016/j.a lit.2020.05.003

27. Takamiya A, Takeda M, Yoshida A, Kiyama H (2001) Expression of serine protease inhibitor 3 in ocular tissues in endotoxin-induced uveitis in rat. Invest Ophthalmol Vis Sci 42(11):2427-2433

28. Toris CB, Pederson JE (1987) Aqueous humor dynamics in experimental iridocyclitis. Invest Ophthalmol Vis Sci 28(3):477-481

29. Torok Z, Peto T, Csosz E, Tukacs E, Molnar A, Maros-Szabo Z, Berta A, Tozser J, Hajdu A, Nagy V, Domokos B, Csutak A (2013) Tear fluid proteomics multimarkers for diabetic retinopathy screening. BMC Ophthalmol 13(1):40. https://doi.org/10.1186/1471-2415-13-40

30. Yui S, Nakatani Y, Mikami M (2003) Calprotectin (S100A8/S100A9), an inflammatory protein complex from neutrophils with a broad apoptosisinducing activity. Biol Pharm Bull 26(6):753-760. https://doi.org/10.1248/ bpb.26.753

\section{Publisher's Note}

Springer Nature remains neutral with regard to jurisdictional claims in published maps and institutional affiliations.

\section{Submit your manuscript to a SpringerOpen ${ }^{\circ}$ journal and benefit from:}

- Convenient online submission

- Rigorous peer review

- Open access: articles freely available online

- High visibility within the field

- Retaining the copyright to your article

Submit your next manuscript at $\boldsymbol{\nabla}$ springeropen.com 